\title{
Odwracalne ciecze emulsyjne o wysokim stężeniu fazy wewnętrznej (HIPR)
}

\section{Reversible emulsion fluids with a high internal phase ratio (HIPR)}

\author{
Sławomir Błaż \\ Instytut Nafty i Gazu - Państwowy Instytut Badawczy
}

\begin{abstract}
STRESZCZENIE: Najczęściej stosowanymi płuczkami do wiercenia otworów na osnowie oleju są płuczki inwersyjne. Stosunek fazy olejowej do wodnej w inwersyjnych płuczkach wiertniczych zawiera się w zakresie od 65/35 do 90/10, przy czym najczęściej wynosi od 70/30 do 80/20. Płuczki przy takich stosunkach fazy olejowej do wodnej charakteryzują się wysoką stabilnością i odpowiednimi parametrami reologiczno-strukturalnymi, pozwalającymi na szeroki zakres regulacji gęstości płuczki. Jedną z wad płuczek inwersyjnych jest ich koszt (ze względu na zawartość oleju) i problemy środowiskowe związane z odpadami i zagospodarowaniem zaolejonych zwiercin. W artykule przedstawiono badania laboratoryjne zmierzające do opracowania składu płuczki inwersyjnej o ograniczonej zawartości fazy olejowej i wysokim stężeniu fazy wewnętrznej (ang. high internal phase ratio - HIPR). Płuczki o współczynniku o/w poniżej lub równym 50/50 różnią się od konwencjonalnych płuczek inwersyjnych pod względem składu i właściwości. Z powodu większego stężenia zdyspergowanej fazy wewnętrznej płuczki te charakteryzują się zmniejszoną stabilnością i wysokimi parametrami reologiczno-strukturalnymi. Utrzymanie odpowiednich parametrów reologiczno-strukturalnych płuczki i jej wysokiej stabilności możliwe jest tylko poprzez wykorzystanie odpowiednich środków chemicznych dostosowanych do danego układu emulsyjnego, o określonym stosunku fazy olejowej do wodnej. W tego rodzaju płuczkach możliwe jest także, ze względu na wyższe stężenie fazy wewnętrznej, częściowe regulowanie gęstości płuczki fazą wodną, którą mogą stanowić roztwory soli, i ograniczanie w ten sposób zawartości substancji stałych (materiałów obciążających) w płuczce. Opracowany system płuczkowy powinien być bardziej ekonomiczny, charakteryzować się ograniczoną toksycznością przy jednoczesnym zachowaniu eksploatacyjnych zalet płuczki inwersyjnej. Płuczki tego rodzaju mogą znaleźć zastosowanie zarówno podczas przewiercania reaktywnych formacji łupkowych, warstw solnych, gipsu, anhydrytu, jak też służyć do dowiercania horyzontów produktywnych oraz do prac rekonstrukcyjnych prowadzonych w odwiertach ropno-gazowych.
\end{abstract}

Słowa kluczowe: płuczka na osnowie oleju, inwersyjna płuczka wiertnicza, wysokie stężenie fazy wewnętrznej emulsji, stabilność emulsji, faza ciągła emulsji.

\begin{abstract}
Invert muds are the most commonly used oil-based drilling muds. The oil to water phase ratio in invert drilling muds ranges from $65 / 35$ up to 90/10, with the most common ones ranging from 70/30 to 80/20. At these oil to water phase ratios, the drilling mud is characterized with high stability and appropriate rheological and structural parameters allowing to adjust drilling mud density in a wide range. One of the disadvantages of invert muds is their cost (due to oil content) and environmental problems associated with waste and management of oily drill cuttings. Taking into account the properties of oil-based muds, the article presents laboratory tests aimed at developing the composition of an invert mud with a limited oil phase content and high internal phase ratio (HIPR). Drilling muds with an o/w ratio less or equal to 50/50 vary from conventional inversion muds in terms of their composition and properties. Due to the higher concentration of the dispersed inner phase, muds have reduced stability and high rheological and structural parameters. Maintaining the appropriate rheological and structural parameters of the drilling mud and its high stability is possible only through the use of appropriate chemicals adapted to the emulsion system with a specific oil to water phase ratio. In the drilling muds of this type it is also possible, due to the higher concentration of the internal phase, to partially adjust the density of the mud with the water phase, such as salt solutions, thus limiting the solids content (weighting agents) in the mud. The developed mud system should be more economical, have a reduced toxicity, while maintaining the operational advantages of invert mud. These types of muds can be used during the drilling of reactive shale formations, salt layers, gypsum and anhydrite layers, as well as for drilling productive horizons and for reconstruction works carried out in oil and gas wells.
\end{abstract}

Key words: oil-based mud, invert drilling mud, high internal phase ratio, emulsion stability, continuous phase of emulsion.

Autor do korespondencji: S. Błaż, e-mail: slawomir.blaz@inig.pl

Artykuł nadesłano do Redakcji: 24.11.2020 r. Zatwierdzono do druku: 02.03.2021 r. 


\section{Wstęp}

Do wiercenia otworów za ropą naftową i gazem ziemnym stosowanych jest wiele rodzajów płuczek wiertniczych. Wybór odpowiedniej płuczki wymaga starannego wyważenia zarówno jej zalet, jak i wad, a także optymalnego doboru jej właściwości, dostosowanych do panujących warunków geologiczno-technicznych. Najczęściej do wiercenia otworów, głównie z uwagi na koszt i ograniczenia środowiskowe, stosowane są płuczki wodnodyspersyjne (ang. water-based mud). Jednak w szczególnych warunkach, np. występowania wysokich ciśnień i temperatur, do wiercenia głębokich otworów zalecane są płuczki na osnowie oleju (ang. oil-based mud).

Płuczki olejowodyspersyjne mają wpływ m.in. na: poprawę stabilności otworu, zwłaszcza podczas przewiercania formacji łupkowych; tworzenie na ścianach otworu cienkich osadów filtracyjnych; doskonałe smarowanie przewodu wiertniczego i narzędzi wiertniczych; przewiercanie złóż soli bez jej rozpuszczania. Znakomite właściwości smarne płuczek inwersyjnych pozwalają na wiercenie otworów kierunkowych i horyzontalnych, umożliwiają zmniejszenie oporów tarcia i momentu obrotowego (Deville, 2010; Maghrabi et al., 2011; Amani et al., 2012; Jasiński, 2012; Alford et al., 2014; Błaż, 2015; Paswan et al., 2016; Hajiabadi et al., 2020).

Najczęściej stosowanymi płuczkami na osnowie oleju są płuczki inwersyjne. Płuczka inwersyjna składa się z dwóch faz: olejowej i wodnej. Fazę olejową najczęściej tworzą oleje mineralne bądź syntetyczne. Faza olejowa stanowi fazę ciągłą emulsji, bardzo często nazywa się ją także ośrodkiem dyspersyjnym. Można się również spotkać $\mathrm{z}$ określeniem faz emulsji jako fazy wewnętrznej i fazy zewnętrznej. Natomiast fazą wodną jest roztwór solanki, która stanowi fazę wewnętrzną emulsji. Czynnikiem zapewniającym stabilność takiego układu dyspersyjnego jest emulgator. Zadanie emulgatorów polega na obniżeniu napięcia powierzchniowego na powierzchni międzyfazowej oraz na zapobieganiu łączeniu się kropel fazy rozproszonej (koalescencji) dzięki utworzeniu na ich powierzchni ochronnej otoczki. W zależności od tego, która część emulgatora przeważa, emulgator może być rozpuszczany w oleju, przyczyniając się do utworzenia emulsji typu w/o, lub w wodzie, ułatwiając otrzymanie emulsji typu o/w. Zatem rodzaj emulsji, czyli to, która z faz (olej czy woda) jest fazą rozproszoną, a która rozpraszającą, w głównej mierze zależy od rodzaju zastosowanego emulgatora.

Emulsje typu olej w wodzie są zazwyczaj stabilizowane zarówno przez stabilizację elektrostatyczną (podwójna warstwa elektryczna między dwiema fazami), jak i stabilizację sferyczną (siły van der Waalsa). Natomiast emulsje inwersyjne typu woda w oleju są zwykle stabilizowane tylko przez stabilizację sferyczną. W związku z tym inwersyjne emulsje są na ogół trudniejsze do stabilizacji, szczególnie na wyższych poziomach fazy wewnętrznej, i często tworzą ciecze o wysokiej lepkości (Holmberg et al., 2002; Whitby et al., 2008; Fernandez et al., 2014, Gacek i Berg, 2015; Liu et al., 2020; Tiwari et al. 2020).

Stosunek fazy olejowej do wodnej w inwersyjnych płuczkach wiertniczych zawiera się w zakresie od 65/35 do 90/10, przy czym najczęściej wynosi od 70/30 do 80/20. Kilka czynników determinuje takie zakresy, w tym m.in. zawartość fazy stałej w płuczce, w tym materiałów obciążających, celem zagwarantowania odpowiedniej gęstości płuczki dostosowanej do warunków geologiczno-technicznych. Zwiększona zawartość fazy olejowej w płuczce inwersyjnej jest także wymagana, aby nadać materiałom obciążającym i zwiercinom odpowiednią zwilżalność olejem. Przy takich stosunkach fazy olejowej do wodnej płuczki inwersyjne charakteryzują się wysoką odpornością temperaturową i odpowiednimi parametrami reologiczno-strukturalnymi, pozwalającymi na wiercenia w warunkach wysokiego ciśnienia i temperatury (ang. high temperature, high pressure - HTHP). Jedną z wad płuczek inwersyjnych jest ich koszt (ze względu na zawartość oleju) i problemy środowiskowe związane z odpadami i zagospodarowaniem zaolejonych zwiercin. Czasami wysokie koszty mogą być zrównoważone poprzez zastosowanie płuczki do wiercenia kilku lub kilkunastu otworów. W przypadku wykorzystywania płuczek inwersyjnych trudniejsze jest także w porównaniu do płuczek wodnodyspersyjnych ich serwisowanie. Kosztowne są również straty płuczki podczas wiercenia w strefach występowania kawern i skał o dużej porowatości. Stosowanie płuczek inwersyjnych wymaga także przeprowadzania specjalnego oczyszczania otworu przed zabiegiem cementowania i strefy przyodwiertowej przed eksploatacją.

W niektórych krajach stosowanie do wiercenia płuczek olejowodyspersyjnych jest ograniczone lub zakazane z uwagi na możliwość zanieczyszczenia gleby i wód gruntowych warstw wodonośnych (Jones et al., 2006; Rojas et al., 2007; Karimi et al., 2009; Amani, 2012; Kulkarni i Jamison, 2015; Luster et al., 2015; Elkatatny, 2019; Geng et al., 2019; Paswan et al., 2020).

Jednym ze sposobów obniżenia kosztów stosowania płuczki inwersyjnej oraz zmniejszenia jej toksycznego wpływu na środowisko jest możliwość opracowania składów płuczek inwersyjnych o ograniczonej zawartości fazy olejowej i wysokim stężeniu fazy wewnętrznej (ang. high internal phase ratio - HIPR). Płuczki o współczynniku o/w poniżej lub równym 50/50 różnią się od konwencjonalnych pluczek inwersyjnych pod względem składu i właściwości. Z powodu większego stężenia zdyspergowanej fazy wewnętrznej zmniejsza się jej trwałość i wzrastają parametry reologiczno-strukturalne płuczki, wykraczając poza akceptowany zakres (Luster et al., 2015). 
Mając na względzie właściwości płuczek olejowodyspersyjnych, w artykule przedstawiono cykl badań laboratoryjnych zmierzających do opracowania składu płuczki inwersyjnej o ograniczonej zawartości fazy olejowej i wysokim stężeniu fazy wewnętrznej (HIPR). Płuczki o współczynniku o/w poniżej lub równym 50/50 różnią się od konwencjonalnych płuczek inwersyjnych pod względem składu i właściwości. Z powodu większego stężenia zdyspergowanej fazy wewnętrznej płuczki te charakteryzują się zmniejszoną stabilnością i wysokimi parametrami reologiczno-strukturalnymi. Utrzymanie odpowiednich parametrów reologiczno-strukturalnych płuczki i jej wysokiej stabilności możliwe jest tylko poprzez użycie odpowiednich środków chemicznych dostosowanych do danego układu emulsyjnego, o określonym stosunku fazy olejowej do wodnej. W tego rodzaju płuczkach możliwe jest także, ze względu na wyższe stężenie fazy wewnętrznej, częściowe regulowanie gęstości płuczki fazą wodną, którą mogą stanowić roztwory soli, i ograniczanie w ten sposób zawartości substancji stałych (materiałów obciążających) w płuczce.

\section{Metodyka badań}

Badania laboratoryjne nad opracowaniem składów inwersyjnych płuczek wiertniczych o wysokim stężeniu fazy wewnętrznej HIPR rozpoczęto od doboru emulgatorów do emulsji o stosunku zmieszania faz o/w wynoszącym 40/60. Emulsje sporządzano w następujący sposób: do $40 \mathrm{~cm}^{3}$ oleju dodawano wstępnie wybrane emulgatory w różnych ilościach, następnie mieszano i dodawano fazę wodną, którą stanowił 35-procentowy roztwór $\mathrm{CaCl}_{2}$.

Płuczki inwersyjne o wysokiej zawartości fazy wodnej mogą łatwo stracić swoją stabilność i ulec rozkładowi na fazę olejową i wodną. Wyselekcjonowanie zespołu emulgatorów o najskuteczniejszym działaniu wymagało sprawdzenia dużej grupy środków o działaniu emulgującym. Tworzenie emulsji inwersyjnych prowadzono w związku z tym na drodze dodatku różnych rodzajów emulgatorów i sprawdzania jakości powstałych emulsji za pomocą miernika elektrycznej stabilności emulsji firmy Ofite.

Emulsion Stability Meter określa wartość ES (ang. electrical stability) przez przyłożenie napięcia pomiędzy parą równoległych płaskich elektrod płytowych, które są zanurzone w płynie. Powstały prąd pozostaje na niskim poziomie aż do osiągnięcia napięcia progowego (61 A \pm 5 A). Następnie zwiększa się napięcie prądu do punktu, w którym następuje tzw. przebicie. Wartość napięcia jest podawana w woltach. Jeśli przebicie nastąpi przy niskim poziomie napięcia, oznacza to emulsję o/w, w przypadku wystąpienia przebicia elektrycznego dopiero przy wysokim napięciu mamy do czynienia z emulsją typu w/o. Im wyższa wartość ES, tym stabilniejsza powstaje emulsja.

W toku prowadzonych badań spośród najefektywniejszych emulgatorów wybrano środki powierzchniowo czynne, których użycie gwarantowało powstanie trwałych emulsji o elektrycznej stabilności powyżej $300 \mathrm{~V}$. Następnie z udziałem wybranych emulgatorów przystąpiono do badań określenia ich optymalnych ilości do danego rodzaju płuczki inwersyjnej o określonym stosunku fazy olejowej do wodnej.

Badania stabilności płuczek inwersyjnych o różnym stosunku fazy olejowej do wodnej prowadzono również za pomocą urządzenia Turbiscan Tower, które umożliwia pomiar stabilności zawiesin, emulsji i pian. Analizator działa na zasadzie analizy światła wielokrotnie rozproszonego (przechodzącego i wstecznie odbitego). Urządzenie wykrywa zmiany stabilności w fazie początkowej do 200 razy szybciej niż w przypadku obserwacji wzrokowej. Dołączone oprogramowanie umożliwia między innymi: wyliczenie kinetyki zmian oraz identyfikację występujących zjawisk, wyliczenie zmiany średniej średnicy i koncentracji cząstek, obliczenie TSI (ang. Turbiscan stability index) - indeksu stabilności - bezwymiarowego parametru charakteryzującego stabilność próbki i pozwalającego na szybkie porównanie próbek. Obliczenie indeksu TSI jest przeprowadzane na podstawie danych podstawowych otrzymywanych w wyniku pomiaru sygnału światła przechodzącego T i wstecznie odbitego BS. Następnie sumowane są wszystkie zmiany sygnału w próbce, aby otrzymać unikalną liczbę odzwierciedlającą destabilizację danej próbki. Im większa liczba TSI, tym próbka bardziej niestabilna.

Następnie dla opracowanych płuczek typu HIPR wykonano badania doboru środka zwilżającego. Badania doboru środków zwilżających prowadzono na płuczce inwersyjnej o stosunku fazy olejowej do wodnej wynoszącym 30/70, o gęstości $1400 \mathrm{~kg} / \mathrm{m}^{3}$. Badania polegały na skażaniu płuczki bentonitem, który charakteryzuje się silnymi właściwościami pęczniejącymi w obecności wody. Proces skażania rozpoczęto od dodania $5 \%$ bentonitu, następnie płuczkę poddano mieszaniu przez $30 \mathrm{~min}$ i pozostawiono na 24 godz. Po upływie założonego czasu sprawdzano stabilność elektryczną płuczki (ES). Proces skażania płuczki prowadzono do 20\% zawartości bentonitu.

Dla płuczek inwersyjnych typu HIPR o stosunku fazy olejowej do wodnej 50/50, 40/60, 70/30 i 20/80 na podstawie badań dyspersji określone zostały ich właściwości inhibicyjne w stosunku do przewiercanych skał ilasto-łupkowych.

Sprawdzono także odporność opracowanych płuczek inwersyjnych typu HIPR na działanie wysokiej temperatury i ciśnienia. Odporność temperaturową płuczek określano poprzez pomiar ich parametrów reologiczno-strukturalnych za pomocą wysokotemperaturowego i wysokociśnieniowego wiskozymetru Ofite 77. 
Płuczki badano zarówno w cyklu podgrzewania, jak i schładzania w zakresie temperatur od $20^{\circ} \mathrm{C}$ do $120^{\circ} \mathrm{C}$.

W kolejnym etapie badań sprawdzono wpływ działania wysokiej temperatury i ciśnienia na filtrację płuczek inwersyjnych. Filtrację płuczek badano na prasie filtracyjnej HPHT w temperaturze $120^{\circ} \mathrm{C}$. Badania wpływu podwyższonej temperatury i ciśnienia na wartość filtracji przeprowadzono dla płuczek inwersyjnych o stosunku fazy olejowej do wodnej wynoszącym 50/50, 40/60, 70/30 i 25/75.

\section{Wyniki badań laboratoryjnych}

Badania laboratoryjne rozpoczęto od sporządzenia emulsji typu w/o z zastosowaniem emulgatorów przeznaczonych do konwencjonalnych płuczek inwersyjnych o stosunku fazy olejowej do wodnej w zakresie 70/30-90/10 (tab. 1, poz. 1). Po wykonaniu wstępnych badań ustalono, że nie jest możliwe z tego typu emulgatorami otrzymanie stabilnych emulsji inwersyjnych ze zwiększoną zawartością fazy wodnej. Elektryczna stabilność sporządzonej emulsji o stosunku o/w równym 40/60 wynosiła 110 V. Płuczki inwersyjne o wysokim stężeniu fazy wewnętrznej wymagają użycia innych rodzajów emulgatorów, dostosowanych do innej specyfiki emulsji.

$\mathrm{W}$ tabeli 1 przedstawiono badania emulsji z zastosowaniem różnych rodzajów emulgatorów. Celem badania był dobór emulgatorów do cieczy emulsyjnych typu w/o o wysokim stężeniu fazy wewnętrznej, przy których udziale można uzyskać stabilne emulsje.

Wstępnie przeprowadzone testy sporządzonych emulsji inwersyjnych wykazały, że możliwe jest uzyskanie emulsji inwersyjnej (ES powyżej 300 V) o stosunku fazy olejowej do wodnej równym 40/60. Stabilność elektryczną wynoszącą $360 \mathrm{~V}$ stwierdzono w emulsji przygotowanej z zastosowaniem trzech emulgatorów: E4, R2600 i KAD (tab. 1, poz. 4). Wygrzanie tej emulsji w temperaturze $50^{\circ} \mathrm{C}$ przez 24 godziny spowodowało obniżenie jej stabilności do $50 \mathrm{~V}$. Znacznie stabilniejszą emulsję na działanie temperatury otrzymano przy zastosowaniu emulgatorów E4 i GAEEO. Stabilność elektryczną emulsji (ES) określono w $20^{\circ} \mathrm{C}$ na $440 \mathrm{~V}$, a w temperaturze $50^{\circ} \mathrm{C}$ była niewiele niższa i wynosiła $410 \mathrm{~V}$ (tab. 1, poz. 6). Natomiast najwyższą stabilnością elektryczną zarówno w $20^{\circ} \mathrm{C}$, jak i $50^{\circ} \mathrm{C}$ charakteryzowała się emulsja, w której składzie wykorzystano dwa emulgatory: ENI i ENII (tab. 1, poz. 5).

Uzyskane wartości elektrycznej stabilności emulsji badanych w temperaturach $20^{\circ} \mathrm{C}$ i $50^{\circ} \mathrm{C}$ wskazały, że przy sporządzaniu emulsji o stosunku fazy olejowej do wodnej równym 40/60 należy zastosować emulgator ENI w ilości 4\% i emulgator ENII w ilości 3\%. Przy takim dodatku emulgatorów otrzymano stabilną emulsję o najwyższej stabilności elektrycznej (ES), wynoszącej w temperaturze $20^{\circ}-790 \mathrm{~V}$, a w temperaturze $50^{\circ} \mathrm{C}-670 \mathrm{~V}$ (tab. 1, poz. 5).

Tabela 1. Badania nad opracowaniem składu emulsji inwersyjnej typu HIPR

Table 1. Studies on the development of the HIPR invert emulsion composition

\begin{tabular}{|c|c|c|c|c|}
\hline \multirow{3}{*}{$\begin{array}{c}\mathrm{Nr} \\
\text { emulsji }\end{array}$} & \multirow{3}{*}{\multicolumn{2}{|c|}{$\begin{array}{l}\text { Skład emulsji } \\
\quad\left[\mathrm{cm}^{3}, \mathrm{~g}\right]\end{array}$}} & \multirow{2}{*}{\multicolumn{2}{|c|}{$\begin{array}{c}\text { ES } \\
{[\mathrm{V}]} \\
\text { temperatura }\end{array}$}} \\
\hline & & & & \\
\hline & & & $20^{\circ} \mathrm{C}$ & $50^{\circ} \mathrm{C}$ \\
\hline 1 & $\begin{array}{l}\text { Olej B } \\
\text { Bentonit } \mathrm{H} \\
\text { E4 } \\
\text { E5 } \\
35 \% \mathrm{CaCl}_{2}\end{array}$ & $\begin{array}{c}40 \\
2 \\
3 \\
5 \\
60\end{array}$ & 110 & 70 \\
\hline 2 & $\begin{array}{l}\text { Olej B } \\
\text { Bentonit } \mathrm{H} \\
\text { E4 } \\
\text { LP200 } \\
25 \% \mathrm{CaCl}_{2}\end{array}$ & $\begin{array}{c}40 \\
2 \\
3 \\
5 \\
60\end{array}$ & 40 & 10 \\
\hline 3 & $\begin{array}{l}\text { Olej B } \\
\text { Bentonit } \mathrm{H} \\
\text { E4 } \\
\mathrm{K} 3 \\
35 \% \mathrm{CaCl}_{2}\end{array}$ & $\begin{array}{c}40 \\
2 \\
3 \\
5 \\
60 \\
\end{array}$ & 140 & 70 \\
\hline 4 & $\begin{array}{l}\text { Olej B } \\
\text { Bentonit H } \\
\text { E4 } \\
\text { R2600 } \\
\text { KAD } \\
35 \% \mathrm{CaCl}_{2}\end{array}$ & $\begin{array}{c}40 \\
2 \\
2 \\
1 \\
3 \\
60\end{array}$ & 360 & 50 \\
\hline 5 & $\begin{array}{l}\text { Olej B } \\
\text { Bentonit } \mathrm{H} \\
\text { ENI } \\
\text { ENII } \\
25 \% \mathrm{CaCl}_{2}\end{array}$ & $\begin{array}{c}40 \\
2 \\
4 \\
3 \\
60\end{array}$ & 790 & 670 \\
\hline 6 & $\begin{array}{l}\text { Olej B } \\
\text { Bentonit } \mathrm{H} \\
\text { E4 } \\
\text { GAEEO } \\
35 \% \mathrm{CaCl}_{2}\end{array}$ & $\begin{array}{c}40 \\
2 \\
3 \\
3 \\
60\end{array}$ & 440 & 410 \\
\hline
\end{tabular}

\section{Badania laboratoryjne nad określeniem stabilności uktadów emulsyjnych w zależności od stosunku fazy olejowej do wodnej}

Płuczka inwersyjna charakteryzuje się wysoką stabilnością przy określonym stosunku fazy olejowej do wodnej i każde nadmierne odchylenie od tego optymalnego stosunku obniża jej trwałość. W wyniku zwiększania zawartości fazy wodnej na ogół następuje obniżenie trwałości emulsji, a w niektórych przypadkach może nawet dojść do odwrócenia emulsji typu w/o na o/w. Z uwagi na powyższe przeprowadzono badania laboratoryjne zmierzające do określenia stabilności wytworzonych układów emulsyjnych przy określonym stosunku zmieszania faz. 
Tabela 2. Badania laboratoryjne płuczki inwersyjnej o różnym stosunku fazy olejowej do wodnej

Table 2. Laboratory tests of the invert mud with various oil to water phase ratios

\begin{tabular}{|c|c|c|c|c|c|c|c|c|c|}
\hline \multirow[t]{2}{*}{$\begin{array}{c}\mathrm{Nr} \\
\text { płuczki }\end{array}$} & \multirow{2}{*}{\multicolumn{2}{|c|}{$\begin{array}{c}\text { Skład płuczki } \\
{\left[\mathrm{cm}^{3}, \mathbf{g}, \%\right]}\end{array}$}} & \multirow{2}{*}{$\begin{array}{c}\text { Gęstość } \\
{\left[\mathrm{kg} / \mathrm{m}^{3}\right]} \\
\rho \\
\end{array}$} & \multicolumn{2}{|c|}{$\begin{array}{l}\text { Lepkość } \\
{[\mathrm{mPa} \cdot \mathrm{s}]}\end{array}$} & \multirow{2}{*}{$\begin{array}{c}\text { Granica } \\
\text { płynięcia } \\
\text { [Pa] }\end{array}$} & \multirow{2}{*}{ 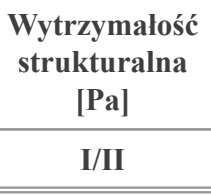 } & \multirow[t]{2}{*}{ TSI } & \multirow[t]{2}{*}{$\begin{array}{l}\text { ES } \\
{[\mathbf{V}]}\end{array}$} \\
\hline & & & & $\eta_{p l}$ & $\eta_{s}$ & & & & \\
\hline \multicolumn{10}{|c|}{ Stosunek fazy olejowej do wodnej 50/50 } \\
\hline 1 & $\begin{array}{l}\text { Olej B } \\
\text { ENI } \\
\text { ENII } \\
35 \% \mathrm{CaCl}_{2}\end{array}$ & $\begin{array}{l}472 \\
37,5 \\
18,5 \\
472 \\
\end{array}$ & 1100 & 15 & 17,5 & 2,4 & $0,48 / 0,96$ & 6,9 & 610 \\
\hline 2 & $\begin{array}{l}\text { Olej B } \\
\text { Bentonit } \mathrm{H} \\
\text { ENI } \\
\text { ENII } \\
35 \% \mathrm{CaCl}_{2}\end{array}$ & $\begin{array}{c}472 \\
20 \\
37,5 \\
18,5 \\
472\end{array}$ & 1100 & 21 & 25,5 & 4,3 & $0,96 / 1,4$ & 0,5 & 580 \\
\hline \multicolumn{10}{|c|}{ Stosunek fazy olejowej do wodnej $40 / 60$} \\
\hline 3 & $\begin{array}{l}\text { Olej B } \\
\text { ENI } \\
\text { ENII } \\
35 \% \mathrm{CaCl}_{2}\end{array}$ & $\begin{array}{c}377 \\
37,5 \\
18,5 \\
566 \\
\end{array}$ & 1140 & 27 & 33 & 5,7 & $1,9 / 2,4$ & 3,6 & 640 \\
\hline 4 & $\begin{array}{l}\text { Olej B } \\
\text { Bentonit } \mathrm{H} \\
\text { ENI } \\
\text { ENII } \\
35 \% \mathrm{CaCl}_{2}\end{array}$ & $\begin{array}{c}425 \\
10,0 \\
37,5 \\
18,5 \\
519\end{array}$ & 1140 & 27 & 32 & 4,8 & $1,9 / 2,4$ & 0,7 & 610 \\
\hline \multicolumn{10}{|c|}{ Stosunek fazy olejowej do wodnej 35/65 } \\
\hline 5 & $\begin{array}{l}\text { Olej B } \\
\text { ENI } \\
\text { ENII } \\
35 \% \mathrm{CaCl}_{2}\end{array}$ & $\begin{array}{c}331 \\
37,5 \\
18,5 \\
613 \\
\end{array}$ & 1160 & 42 & 53 & 10,5 & $3,3 / 4,3$ & 1,5 & 670 \\
\hline \multicolumn{10}{|c|}{ Stosunek fazy olejowej do wodnej 30/70 } \\
\hline 6 & $\begin{array}{l}\text { Olej B } \\
\text { ENI } \\
\text { ENII } \\
35 \% \mathrm{CaCl}_{2}\end{array}$ & $\begin{array}{l}283 \\
37,5 \\
18,5 \\
660 \\
\end{array}$ & 1190 & 50 & 64,5 & 13,9 & $3,8 / 4,3$ & 1,7 & 680 \\
\hline \multicolumn{10}{|c|}{ Stosunek fazy olejowej do wodnej $25 / 75$} \\
\hline 7 & $\begin{array}{l}\text { Olej B } \\
\text { ENI } \\
\text { ENII } \\
35 \% \mathrm{CaCl}_{2}\end{array}$ & $\begin{array}{l}235 \\
37,5 \\
18,5 \\
707\end{array}$ & 1210 & 61 & 89,5 & 27,2 & $6,2 / 7,6$ & 2,0 & 690 \\
\hline \multicolumn{10}{|c|}{ Stosunek fazy olejowej do wodnej $20 / 80$} \\
\hline 8 & $\begin{array}{l}\text { Olej B } \\
\text { ENI } \\
\text { ENII } \\
35 \% \mathrm{CaCl}_{2}\end{array}$ & $\begin{array}{r}189 \\
37,5 \\
18,5 \\
754\end{array}$ & 1230 & 85 & 116,5 & 30,1 & $9,1 / 10,5$ & 0,9 & 630 \\
\hline
\end{tabular}

W tabeli 2 przedstawiono właściwości płuczek inwersyjnych o stosunku fazy olejowej do wodnej wynoszącym od 50/50 do 20/80 sporządzonych przy udziale wybranych emulgatorów. Stabilność elektryczna (ES) przygotowanych płuczek wynosiła od $610 \mathrm{~V}$ przy stosunku o/w równym 50/50 do $630 \mathrm{~V}$ w przypadku płuczek o zawartości fazy wewnętrznej wynoszącej 80\% (tab. 2). Różnice pomiędzy płuczkami można zauważyć głównie w parametrach reologiczno-strukturalnych, wartości indeksu TSI i gęstości. Najmniejszą stabilnością, określoną przez indeks TSI wynoszący 6,9, charakteryzowała się płuczka o stosunku fazy olejowej do wodnej równym 50/50. Niestabilność TSI na poziomie 3,6 określono w płuczce o stosunku fazy olejowej do wodnej wynoszącym 40/60. Wysoka wartość indeksu TSI i niska granica 
płynięcia wskazały na konieczność zwiększenia parametrów reologiczno-strukturalnych w tych płuczkach poprzez wprowadzenie do ich składu bentonitu hydrofobowego lub modyfikację składu frakcji olejowej. W związku z powyższym w dalszych badaniach do składu płuczki o stosunku fazy olejowej do wodnej równym 50/50 wprowadzono bentonit hydrofobowy w ilości 2\% (tab. 2, poz. 2). Dzięki zastosowaniu bentonitu hydrofobowego w płuczce inwersyjnej o stosunku fazy olejowej do wodnej wynoszącym 50/50 granica płynięcia płuczki zwiększyła się do 4,3 Pa, a indeks stabilności próbki obniżył się z 6,9 do 0,5 (tab. 2, poz. 2). Natomiast w płuczce o stosunku fazy olejowej do wodnej równym 40/60 zastosowanie 1\% bentonitu hydrofobowego spowodowało wzrost granicy płynięcia do 4,8 Pa i obniżenie indeksu TSI do 0,7 (tab. 2, poz. 4).

Zmniejszenie stosunku fazy olejowej do wodnej powoduje wzrost parametrów reologiczno-strukturalnych, obniżenie filtracji płuczek w temperaturze $20^{\circ} \mathrm{C}$ do zera oraz niewielkie zmiany w stabilności elektrycznej płuczek, wynoszącej od $610 \mathrm{~V}$ do $690 \mathrm{~V}$ (tab. 2). Opracowany i wstępnie dobrany skład emulgatorów pozwala na uzyskanie płuczek inwersyjnych o zawartości fazy wodnej nawet $75 \%$. Powyżej tej wartości płuczka charakteryzuje się wysokimi parametrami reologiczno-strukturalnymi, lepkością plastyczną $85 \mathrm{mPa} \cdot \mathrm{s}$ i granicą płynięcia 30,1 Pa (tab. 2, poz. 8).

Zawartość fazy wodnej w płuczkach inwersyjnych typu HIPR umożliwia zwiększenie gęstości bez potrzeby dodawania materiałów obciążających. Do gęstości $1230 \mathrm{~kg} / \mathrm{m}^{3}$ płuczka o stosunku fazy olejowej do wodnej równym 20/80 nie wymaga dodawania materiałów obciążających ani środków do zwiększania parametrów reologiczno-strukturalnych. W tego rodzaju płuczkach właściwości reologiczno-strukturalne mogą być częściowo regulowane poprzez niewielką zmianę stosunku fazy olejowej do wodnej. Zmniejszanie stosunku $\mathrm{o} / \mathrm{w}$ powoduje wzrost parametrów reologicznych, natomiast zwiększanie stosunku - ich obniżenie.

Na rysunku 1 przedstawiono kinetykę reakcji płuczek o różnym stosunku fazy olejowej do wodnej. Badanie prowadzono w temperaturze $20^{\circ} \mathrm{C}$ przez 18 godzin. Najwyższą stabilnością wykazały się płuczki o stosunku fazy olejowej do wodnej równym $50 / 50 \mathrm{z}$ dodatkiem $2 \%$ bentonitu $\mathrm{H}$ oraz płuczka o stosunku o/w wynoszącym 40/60 z dodatkiem 1\% bentonitu H, których indeks TSI wynosił od 0,5 do 0,9 (rys. 1). Niską wartość indeksu TSI, równą 0,9 , stwierdzono także dla próbki o stosunku zmieszania faz o/w wynoszącym 20/80. Natomiast niższą stabilnością cechowały się płuczki o stosunku fazy olejowej do wodnej równym 35/65, 30/70 i 25/75, przy których TSI był wyższy i wynosił od 1,5 do 2 (rys. 1). Obliczone wartości indeksu TSI świadczą o dość dobrej stabilności płuczek i odpowiednich parametrach reologiczno-strukturalnych, które powinny zapobiegać sedymentacji fazy stałej.

\section{Badania laboratoryjne nad opracowaniem środka zwiliajacego do pluczki inwersyjnej o wysokiej zawartości fazy wewnętrznej}

W konwencjonalnych płuczkach inwersyjnych o wysokiej zawartości fazy olejowej - od $70 \%$ do $90 \%$ stosowane są

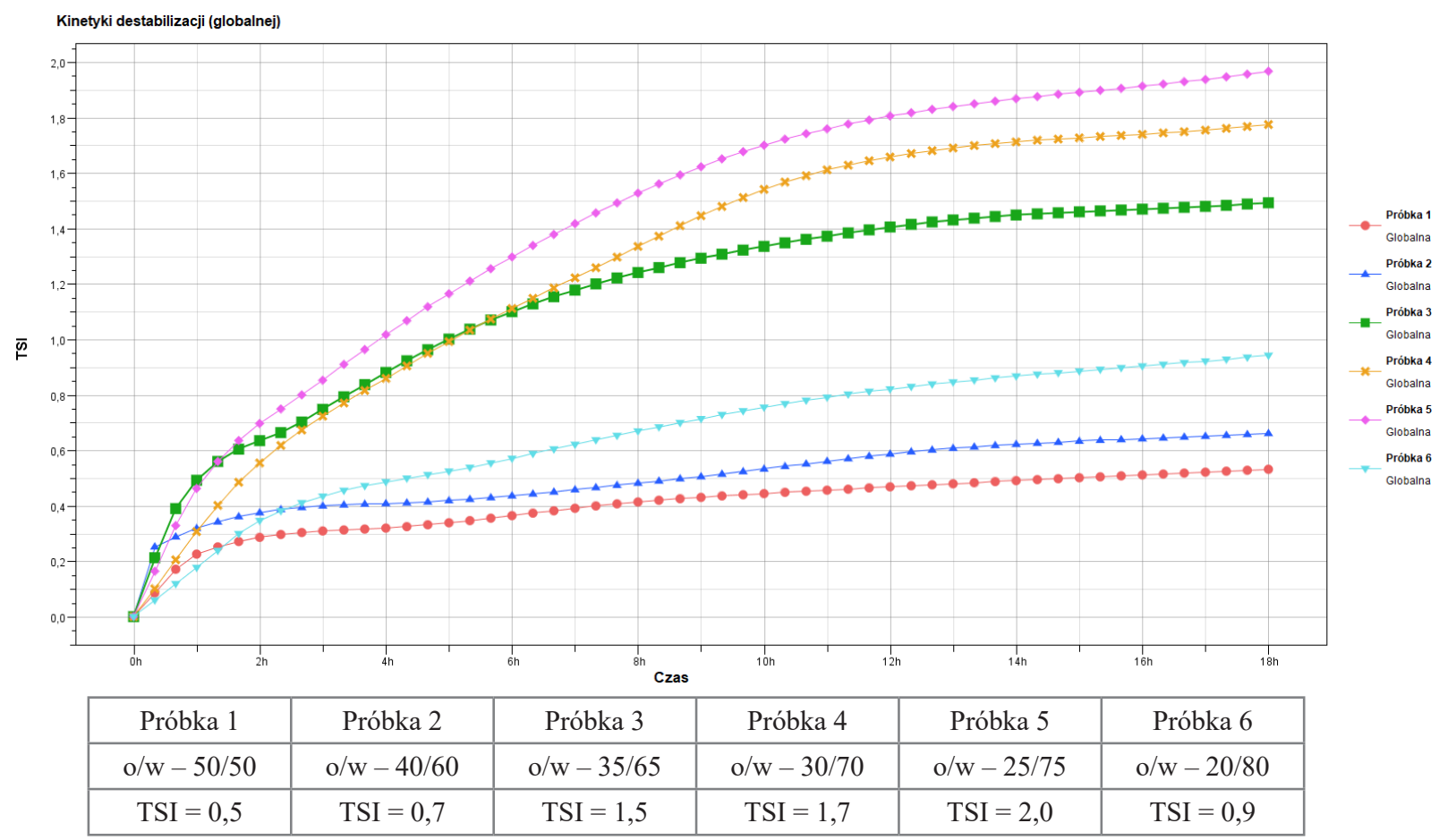

Rys. 1. Kinetyka destabilizacji wybranych płuczek inwersyjnych o różnym stosunku fazy olejowej do wodnej

Fig. 1. Destabilization kinetics of selected invert oil muds with various oil to water phase ratios 
środki zwilżające składające się z części liofilowej, która jest rozpuszczalna $\mathrm{w}$ fazie zewnętrznej emulsji, oraz z niewielkiej części hydrofilowej rozpuszczalnej w fazie wewnętrznej emulsji. Wartość HLB (ang. hydrophilic-lipophilic balance) środków zwilżających powinna wynosić od 7 do 9 . W płuczkach inwersyjnych typu HIPR tego rodzaju środki zwilżające nie spełniają swojego zadania. W związku z powyższym przeprowadzono cykl badań laboratoryjnych zmierzających do wyboru odpowiedniego środka zwilżającego do płuczek inwersyjnych o zwiększonej zawartości fazy wodnej.

Płuczka inwersyjna po sporządzeniu charakteryzowała się stabilnością elektryczną na poziomie około $620 \mathrm{~V}$. Bentonit, jako materiał hydrofilowy, dodany do płuczki w ilości 5\% spowodował obniżenie elektrycznej stabilności emulsji z $620 \mathrm{~V}$ do 440 V. Po zwiększeniu zawartości bentonitu do $10 \%$ wartość ES obniżyła się do $310 \mathrm{~V}$, a po dodatku $20 \%$ bentonitu - do $90 \mathrm{~V}$ (tab. 3).

W przypadku płuczki z dodatkiem środka zwilżającego Hw proces obniżania trwałości emulsji przebiegał znacznie wolniej - przy zawartości 10\% bentonitu wartość ES obniżyła się do $420 \mathrm{~V}$, a przy $20 \%$ bentonitu - do $290 \mathrm{~V}$. Następnie zwiększenie ilości środka zwilżającego Hw do $2 \%$ spowodowało wzrost wartości ES do $390 \mathrm{~V}$ (tab. 3).

Zastosowanie środka zwilżającego $\mathrm{Hw}$ do płuczek inwersyjnych o stosunku fazy olejowej do wodnej poniżej 50/50 powinno przy odpowiednim dawkowaniu na etapie wzbogacania płuczki w zwierconą fazę stałą o charakterze hydrofilowym zapewnić utrzymanie elektrycznej stabilności płuczki inwersyjnej powyżej $300 \mathrm{~V}$ (tab. 3).

W tabeli 4 przedstawiono skład i właściwości płuczki o stosunku fazy olejowej do wodnej równym 30/70. Sporządzona płuczka o gęstości $1190 \mathrm{~kg} / \mathrm{m}^{3}$ charakteryzowała się lepkością plastyczną $50 \mathrm{mPa} \cdot \mathrm{s}$ i granicą płynięcia 13,9 $\mathrm{Pa}$ (tab. 4). Przeprowadzone badania, których wyniki zamieszczono w tabeli 4, wykazały, że istnieje możliwość w zależności od potrzeb dowolnej zmiany stosunku fazy olejowej do wodnej bez konsekwencji utraty ich stabilności. Stosunek fazy olejowej do wodnej można zmieniać w zakresie od 30/70 do 70/30 poprzez stopniowe wprowadzanie do płuczki określonych ilości oleju z dodatkiem emulgatora ENII i środka do zwiększania parametrów reologiczno-strukturalnych.

W tabeli 5 przedstawiono wyniki badań możliwości zamiany inwersyjnej płuczki wiertniczej w płuczkę emulsyjną, którą można w łatwy sposób usunąć $\mathrm{z}$ otworu bez potrzeby stosowania specjalistycznych cieczy myjących. Na podstawie doboru różnych środków powierzchniowo czynnych wybrano środek K30, który dodany do płuczki inwersyjnej o stosunku fazy olejowej do wodnej równym 30/70 spowodował zmianę rodzaju emulsji inwersyjnej na emulsję typu o/w. Stabilność emulsji po dodaniu K30 zmniejszyła się do 2 V.
Tabela 3. Badania laboratoryjne skażania płuczki inwersyjnej o o/w wynoszącym 30/70 bentonitem hydrofilowym

Table 3. Laboratory tests of contamination of o/w - 30/70 invert oil mud with hydrophilic bentonite

\begin{tabular}{|c|c|c|c|}
\hline $\begin{array}{c}\mathrm{Nr} \\
\text { pluczki }\end{array}$ & \multicolumn{2}{|l|}{$\begin{array}{c}\text { Skład płuczki } \\
{\left[\mathrm{cm}^{3}, \mathrm{~g}, \%\right]}\end{array}$} & $\begin{array}{l}\text { ES } \\
{[\mathbf{V}]}\end{array}$ \\
\hline 1 & $\begin{array}{l}\text { Olej B } \\
\text { ENI } \\
\text { ENII } \\
35 \% \mathrm{CaCl}_{2} \\
\text { Baryt }\end{array}$ & $\begin{array}{c}283 \\
37,5 \\
18,5 \\
660\end{array}$ & 620 \\
\hline 2 & $\begin{array}{l}\text { Płuczka } 2 \\
+ \text { bentonit (Bentopol) }\end{array}$ & 5 & 440 \\
\hline 3 & $\begin{array}{l}\text { Płuczka } 3 \\
+ \text { bentonit (Bentopol) } \Sigma 10 \%\end{array}$ & 5 & 310 \\
\hline 4 & $\begin{array}{l}\text { Płuczka } 4 \\
+ \text { bentonit (Bentopol) } \Sigma 15 \%\end{array}$ & 5 & 170 \\
\hline 5 & $\begin{array}{l}\text { Płuczka } 5 \\
+ \text { bentonit (Bentopol) } \Sigma 20 \%\end{array}$ & 5 & 90 \\
\hline 6 & $\begin{array}{l}\text { Olej B } \\
\text { ENI } \\
\text { ENII } \\
35 \% \mathrm{CaCl}_{2} \\
\text { Baryt }\end{array}$ & $\begin{array}{c}283 \\
37,5 \\
18,5 \\
660\end{array}$ & 620 \\
\hline 7 & $\begin{array}{l}\text { Płuczka nr } 6 \\
+ \text { Bentopol }\end{array}$ & 5 & 440 \\
\hline 8 & $\begin{array}{l}\text { Płuczka } 7 \\
+\mathrm{Hw}\end{array}$ & 0,5 & 490 \\
\hline 9 & $\begin{array}{l}\text { Płuczka } 8 \\
+ \text { Bentopol } \Sigma 10 \%\end{array}$ & 5 & 420 \\
\hline 10 & $\begin{array}{l}\text { Płuczka } 9 \\
+ \text { Hw } \Sigma 1 \%\end{array}$ & 0,5 & 460 \\
\hline 11 & $\begin{array}{l}\text { Płuczka } 10 \\
+ \text { Bentopol } \Sigma 15 \%\end{array}$ & 5 & 370 \\
\hline 12 & $\begin{array}{l}\text { Płuczka } 11 \\
+ \text { Hw } \Sigma 1,5 \%\end{array}$ & 0,5 & 410 \\
\hline 13 & $\begin{array}{l}\text { Płuczka } 12 \\
+ \text { Bentopol } \Sigma 20 \%\end{array}$ & 5 & 290 \\
\hline 14 & $\begin{array}{l}\text { Płuczka } 13 \\
+ \text { Hw } \Sigma 2 \%\end{array}$ & 0,5 & 390 \\
\hline
\end{tabular}

Wraz ze spadkiem wartości ES obniżyły się parametry reologiczno-strukturalne płuczki, lepkość plastyczna obniżyła się z $51 \mathrm{mPa} \cdot \mathrm{s}$ do $18 \mathrm{mPa} \cdot \mathrm{s}$, a granica płynięcia z 15,3 $\mathrm{Pa}$ do 1,9 $\mathrm{Pa}$ (tab. 5). Cechą charakterystyczną opracowanych płuczek jest również to, że poprzez dodatek emulgatora ENII w ilości $1 \%$ można z powrotem uzyskać płuczkę inwersyjną o parametrach reologiczno-strukturalnych zbliżonych do płuczki wyjściowej (tab. 5).

\section{Określenie oddzialywania pluczek inwersyjnych typu HIPR na wlaściwości skat ilasto-lupkowych}

Badania dyspersji łupku mioceńskiego przeprowadzono w środowisku płuczek inwersyjnych typu HIPR o stosunku 
Tabela 4. Badania laboratoryjne możliwości regulowania stosunku fazy olejowej do wodnej w płuczkach inwersyjnych w zakresie od $30 / 70$ do $70 / 30$

Table 4. Laboratory tests of the possibility of adjusting the oil to water phase ratio in invert oil muds in the range from $30 / 70$ to $70 / 30$

\begin{tabular}{|c|c|c|c|c|c|c|c|c|c|}
\hline \multirow[t]{2}{*}{$\begin{array}{c}\mathrm{Nr} \\
\text { płuczki }\end{array}$} & \multirow{2}{*}{\multicolumn{2}{|c|}{$\begin{array}{l}\text { Skład płuczki } \\
{\left[\mathrm{cm}^{3}, \mathrm{~g}, \%\right]}\end{array}$}} & \multirow{2}{*}{$\begin{array}{c}\text { Gęstość } \\
{\left[\mathrm{kg} / \mathrm{m}^{3}\right]} \\
\rho\end{array}$} & \multicolumn{2}{|c|}{$\begin{array}{l}\text { Lepkość } \\
{[\mathrm{mPa} \cdot \mathrm{s}]}\end{array}$} & \multirow{2}{*}{$\begin{array}{c}\begin{array}{c}\text { Granica } \\
\text { płynięcia } \\
\text { [Pa] }\end{array} \\
\tau_{y} \\
\end{array}$} & \multirow[t]{2}{*}{$\begin{array}{c}\text { Filtracja } \\
{\left[\mathrm{cm}^{3}\right]}\end{array}$} & \multirow[t]{2}{*}{$\begin{array}{l}\text { ES } \\
{[\mathbf{V}]}\end{array}$} & \multirow[t]{2}{*}{$\begin{array}{c}\text { Stosunek fazy } \\
\text { O/W }\end{array}$} \\
\hline & & & & $\eta_{p l}$ & $\eta_{s}$ & & & & \\
\hline 1 & $\begin{array}{l}\text { Olej B } \\
\text { ENI } \\
\text { ENII } \\
35 \% \mathrm{CaCl}_{2}\end{array}$ & $\begin{array}{l}283 \\
37,5 \\
18,5 \\
660\end{array}$ & 1190 & 50 & 64,5 & 13,9 & 0 & 680 & $30 / 70$ \\
\hline 2 & $\begin{array}{l}\text { Płuczka } 1 \\
+ \text { olej B } \\
+ \text { ENII } \\
+ \text { baryt }\end{array}$ & $\begin{array}{l}156 \\
1,5\end{array}$ & 1200 & 33 & 40 & 6,7 & 0 & 670 & $40 / 60$ \\
\hline 3 & $\begin{array}{l}\text { Płuczka } 2 \\
+ \text { olej B } \\
+ \text { ENII } \\
+ \text { baryt }\end{array}$ & $\begin{array}{l}221 \\
2,2\end{array}$ & 1200 & 30 & 36 & 5,7 & 0 & 850 & $50 / 50$ \\
\hline 4 & $\begin{array}{l}\text { Płuczka } 3 \\
+ \text { olej B } \\
+ \text { ENII } \\
+ \text { baryt }\end{array}$ & $\begin{array}{l}330 \\
3,3\end{array}$ & 1210 & 28 & 32 & 4,8 & 0,2 & 950 & $60 / 40$ \\
\hline 5 & $\begin{array}{l}\text { Płuczka } 4 \\
+ \text { olej B } \\
+ \text { ENII } \\
+ \text { baryt }\end{array}$ & $\begin{array}{l}550 \\
5,5\end{array}$ & 1210 & 25 & 27,5 & 3,8 & 0,2 & 1100 & $70 / 30$ \\
\hline
\end{tabular}

Tabela 5. Badania laboratoryjne wpływu środków powierzchniowo czynnych na właściwości płuczki inwersyjnej o stosunku o/w równym $30 / 70$

Table 5. Laboratory tests of the influence of surfactants on the properties of invert oil mud with an o/w ratio of 30/70

\begin{tabular}{|c|c|c|c|c|c|c|c|c|}
\hline \multirow[t]{2}{*}{$\begin{array}{c}\mathrm{Nr} \\
\text { płuczki }\end{array}$} & \multicolumn{2}{|c|}{$\begin{array}{l}\text { Skład płuczki } \\
\quad\left[\mathrm{cm}^{3}, \mathrm{~g}\right]\end{array}$} & \multirow{2}{*}{$\begin{array}{c}\text { Gęstość } \\
{\left[\mathrm{kg} / \mathrm{m}^{3}\right]} \\
\rho \\
\end{array}$} & \multicolumn{2}{|c|}{$\begin{array}{l}\text { Lepkość } \\
{[\mathrm{mPa} \cdot \mathrm{s}]}\end{array}$} & \multirow{2}{*}{$\begin{array}{c}\text { Granica } \\
\text { płynięcia } \\
\text { [Pa] }\end{array}$} & \multirow{2}{*}{ 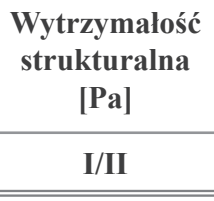 } & \multirow[t]{2}{*}{$\begin{array}{l}\text { ES } \\
{[\mathbf{V}]}\end{array}$} \\
\hline & & & & $\eta_{p l}$ & $\eta_{s}$ & & & \\
\hline 1 & $\begin{array}{l}\text { Olej B } \\
\text { ENI } \\
\text { ENII } \\
35 \% \mathrm{CaCl}_{2} \\
+ \text { baryt }\end{array}$ & $\begin{array}{c}283 \\
37,5 \\
18,5 \\
660\end{array}$ & 1200 & 51 & 67 & 15,3 & $3,8 / 4,3$ & 620 \\
\hline 2 & $\begin{array}{l}\text { Płuczka } 1 \\
+\mathrm{K} 30\end{array}$ & 20 & 1200 & 18 & 20 & 1,9 & $0,48 / 0,48$ & 2 \\
\hline 3 & $\begin{array}{l}\text { Płuczka } 2 \\
\text { ENII }\end{array}$ & 10 & 1200 & 53 & 70 & 16,7 & $4,3 / 4,8$ & 950 \\
\hline
\end{tabular}

fazy olejowej do wodnej wynoszącym 50/50, 40/60, 30/70, 20/80 oraz dla porównania dla płuczki o stosunku równym 80/20. Badania te wykazały, że łupek mioceński w środowisku badanych płuczek nie dysperguje. Średnie wartości odzysku łupku mioceńskiego dyspergowanego w badanych płuczkach wynosiły od 98\% do 100\% (rys. 2). Najmniejsze wartości odzysku łupku mioceńskiego, wynoszące 98\%, odnotowano dla płuczki o stosunku fazy olejowej do wodnej wynoszącym
50/50 i 40/60. Z uwagi na zmniejszanie się stabilności płuczek inwersyjnych wraz ze wzrostem temperatury - przeprowadzono dodatkowe badania dyspersji łupku mioceńskiego w temperaturze $100^{\circ} \mathrm{C}$. Ilości odzysku łupku mioceńskiego dyspergowane w temperaturze $100^{\circ} \mathrm{C}$ były niewiele niższe i wynosiły od 94\% do 98\% (rys. 3). Najmniejszą wartość odzysku łupku, równą 94\%, stwierdzono dla płuczki inwersyjnej o stosunku fazy olejowej do wodnej wynoszącym 20/80. 


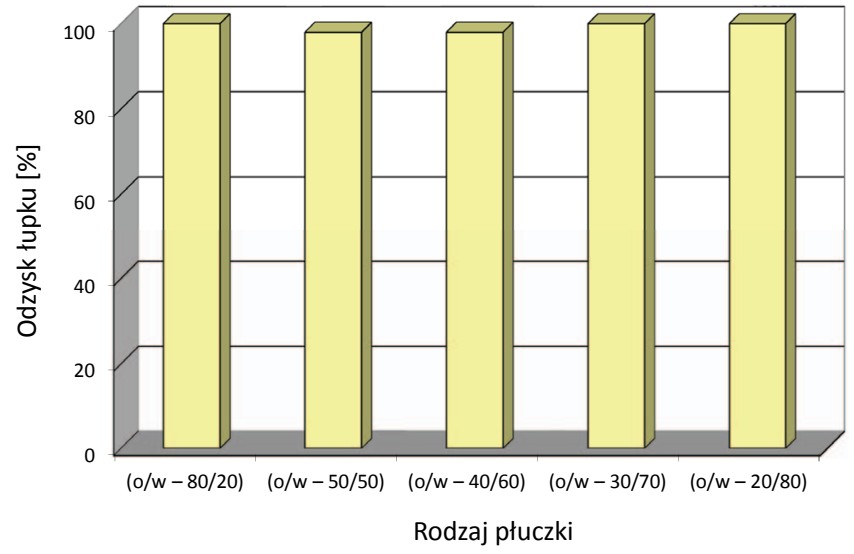

Rys. 2. Wartości odzysku łupku mioceńskiego dyspergowanego w płuczkach inwersyjnych o różnym stosunku fazy olejowej do wodnej w temperaturze $20^{\circ} \mathrm{C}$

Fig. 2. Values of recovery of Miocene shale dispersed in invert mud with various oil to water phase ratios at $20^{\circ} \mathrm{C}$

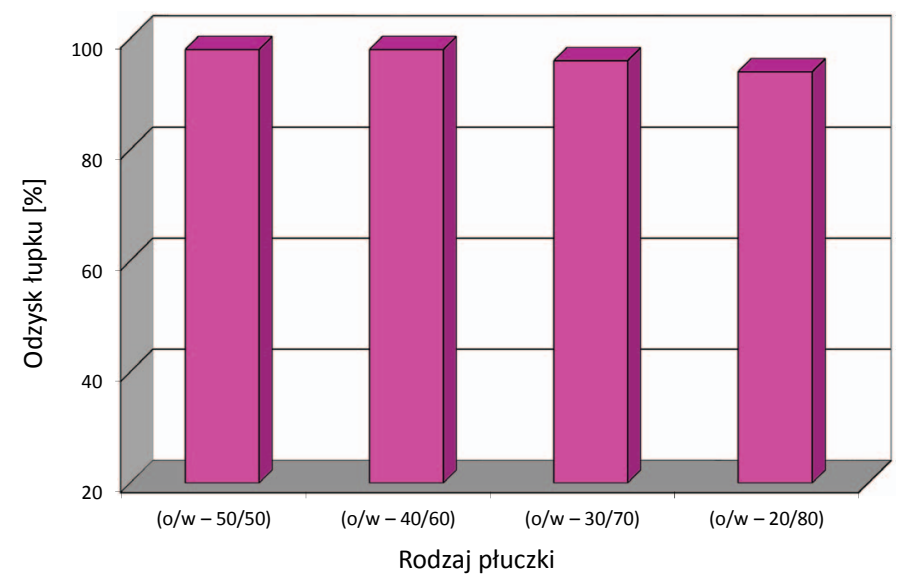

Rys. 3 Wartości odzysku łupku mioceńskiego dyspergowanego w płuczkach inwersyjnych o różnym stosunku fazy olejowej do wodnej w temperaturze $100^{\circ} \mathrm{C}$

Fig. 3. Values of recovery of Miocene shale dispersed in invert mud with various oil to water phase ratios at $100^{\circ} \mathrm{C}$

\section{Określenie wplywu podwyższonej temperatury na wlaściwości reologiczno-strukturalne i filtracje opracowanych pluczek inwersyjnych typu HIPR}

Do badań wytypowano dwie płuczki inwersyjne typu HIPR, o stosunku fazy olejowej do wodnej wynoszącym 50/50 i 30/70, obciążonych barytem do gęstości $1200 \mathrm{~kg} / \mathrm{m}^{3}$. Płuczki badano zarówno w cyklu podgrzewania, jak i schładzania w zakresie temperatur od $20^{\circ} \mathrm{C}$ do $120^{\circ} \mathrm{C}$. Wyniki pomiarów przedstawiono na rysunkach od 4 do $7 \mathrm{w}$ formie wykresu zmian lepkości plastycznej i granicy płynięcia od temperatury. Płuczka inwersyjna o stosunku fazy olejowej do wodnej równym 50/50 w temperaturze $20^{\circ} \mathrm{C}$ i pod ciśnieniem atmosferycznym charakteryzowała się lepkością plastyczną $34 \mathrm{mPa} \cdot \mathrm{s}$ i granicą płynięcia 7,2 Pa (rys. 4 i 5). Płuczkę inwersyjną o przedstawionych właściwościach poddano podgrzewaniu do temperatury $120^{\circ} \mathrm{C}$.
W wyniku stopniowego zwiększania temperatury lepkość plastyczna płuczki ulega obniżeniu. W temperaturze $50^{\circ} \mathrm{C}$ lepkość plastyczna płuczki zmniejsza się do $23 \mathrm{mPa} \cdot \mathrm{s}$, w $90^{\circ} \mathrm{C}-$ do $21 \mathrm{mPa} \cdot \mathrm{s}$, a w temperaturze $120^{\circ} \mathrm{C}-$ do wartości $20 \mathrm{mPa} \cdot \mathrm{s}$ (rys. 4). Zmiany granicy płynięcia w wyniku działania temperatury przebiegają podobnie do temperatury $120^{\circ} \mathrm{C}$, tzn. wraz ze wzrostem temperatury następuje niewielki systematyczny spadek wartości granicy płynięcia. $\mathrm{W}$ temperaturze $90^{\circ} \mathrm{C}$ granica płynięcia obniża się do $5,7 \mathrm{~Pa}$, a w $120^{\circ} \mathrm{C}$ - do wartości 5,3 $\mathrm{Pa}$ (rys. 5). Następnie w cyklu schładzania płuczka odbudowuje swoje parametry do wartości zbliżonych do płuczki przed wygrzaniem (lepkość plastyczna powraca do wartości wyjściowej $34 \mathrm{mPa} \cdot \mathrm{s}$, a granica płynięcia wzrasta do 7,6 Pa (rys. 4 i 5).

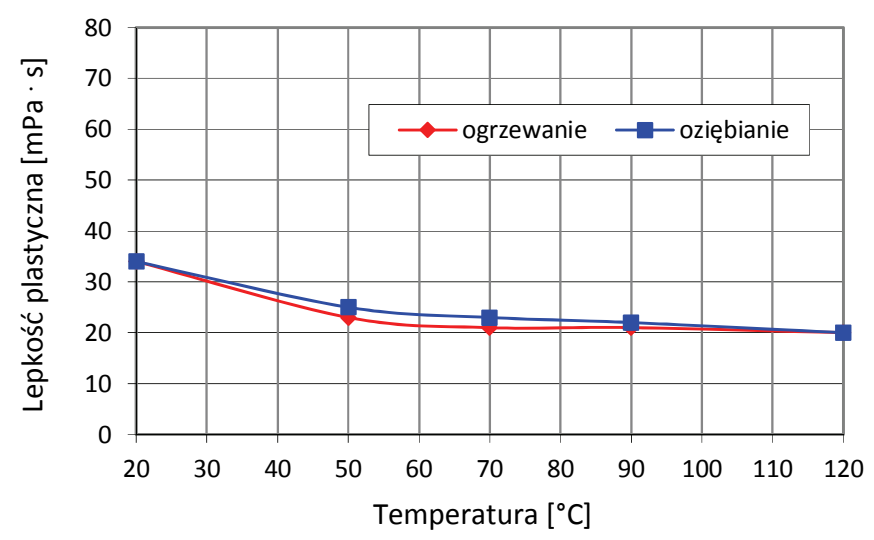

Rys. 4. Zmiany lepkości plastycznej płuczki inwersyjnej o stosunku fazy olejowej do wodnej równym 50/50 w zależności od zmian temperatury

Fig. 4. Changes in the plastic viscosity of invert oil mud with an oil to water ratio of 50/50 depending on temperature changes

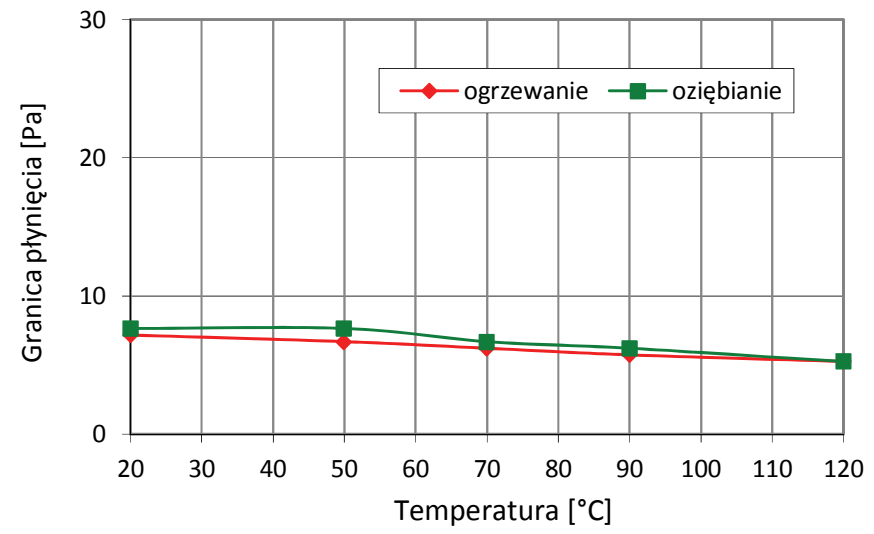

Rys. 5. Zmiany granicy płynięcia płuczki inwersyjnej o stosunku fazy olejowej do wodnej wynoszącym 50/50 w zależności od zmian temperatury

Fig. 5. Changes in the yield point of invert oil mud with an oil to water ratio of 50/50 depending on temperature changes

Płuczka inwersyjna o stosunku fazy olejowej do wodnej równym $30 / 70 \mathrm{w}$ temperaturze $20^{\circ} \mathrm{C}$ charakteryzowała się lepkością plastyczną $61 \mathrm{mPa} \cdot \mathrm{s}$ i granicą płynięcia $16,3 \mathrm{~Pa}$ 
(rys. 6 i 7). W wyniku stopniowego zwiększania temperatury lepkość plastyczna płuczki ulega obniżeniu. W temperaturze $50^{\circ} \mathrm{C}$ lepkość plastyczna płuczki zmniejsza się do $50 \mathrm{mPa} \cdot \mathrm{s}$, w $90^{\circ} \mathrm{C}$ - do $46 \mathrm{mPa} \cdot \mathrm{s}$, a w temperaturze $120^{\circ} \mathrm{C}$ - do wartości $42 \mathrm{mPa} \cdot \mathrm{s}$ (rys. 6). W cyklu schładzania płuczki do warunków otoczenia następuje odbudowa lepkości plastycznej do wartości $60 \mathrm{mPa} \cdot \mathrm{s}$ (rys. 6). Analizując wykres zmian granicy płynięcia płuczki w zależności od temperatury, można stwierdzić, że obniżanie wartości granicy płynięcia zachodzi do temperatury $50^{\circ} \mathrm{C}$. W temperaturze $50^{\circ} \mathrm{C}$ granica płynięcia osiąga najniższą wartość, wynoszącą 17,2 Pa. Dalszy wzrost temperatury do $120^{\circ} \mathrm{C}$ powoduje zwiększenie granicy płynięcia do 18,6 Pa (rys. 7). W cyklu schładzania płuczki do temperatury otoczenia następuje obniżenie granicy płynięcia do wartości 15,3 Pa (rys. 7). Po ochłodzeniu płuczki do temperatury otoczenia stwierdzono, że wytrzymała ona działanie temperatury $120^{\circ} \mathrm{C}$ i nie uległa rozkładowi na fazę wodną

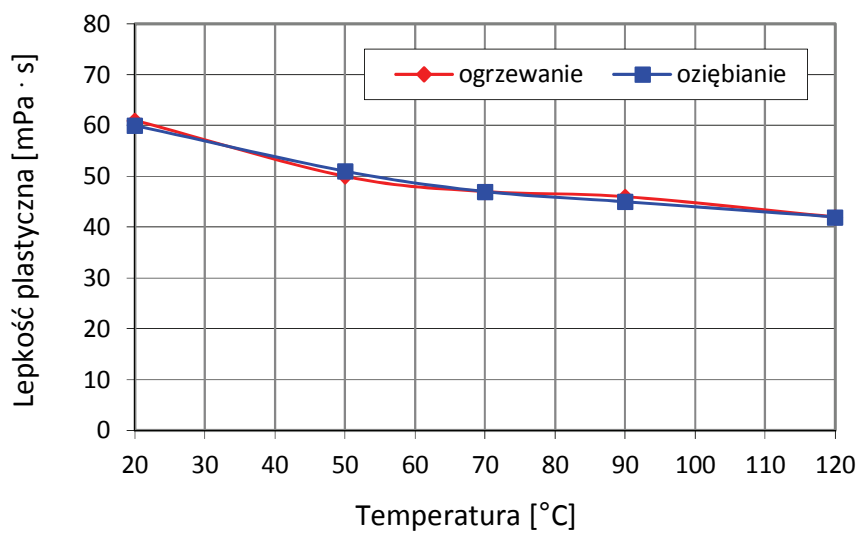

Rys. 6. Zmiany lepkości plastycznej płuczki inwersyjnej o stosunku fazy olejowej do wodnej równym 30/70 w zależności od zmian temperatury

Fig. 6. Changes in the plastic viscosity of invert oil mud with an oil to water ratio of 30/70 depending on temperature changes

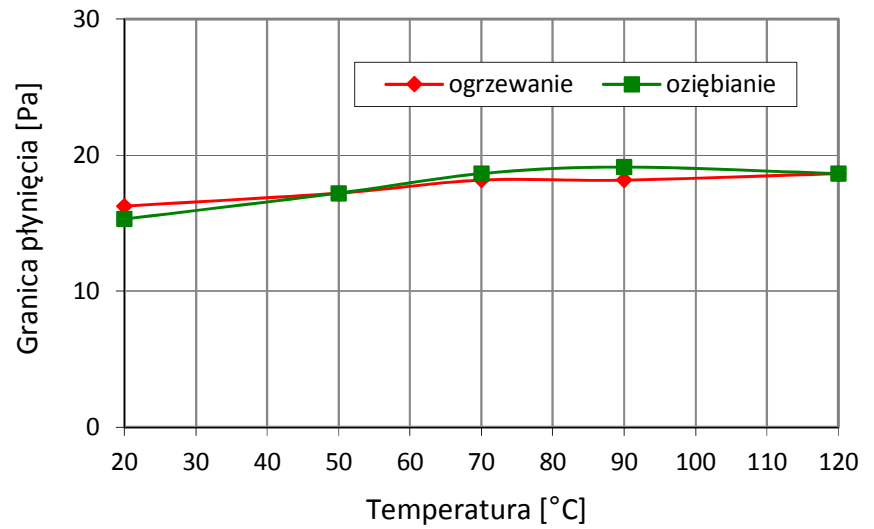

Rys. 7. Zmiany lepkości plastycznej płuczki inwersyjnej o stosunku fazy olejowej do wodnej równym 30/70 w zależności od zmian temperatury

Fig. 7. Changes in the yield point of invert oil mud with an oil to water ratio of 30/70 depending on temperature changes i olejową, a wartość elektrycznej stabilności płuczki inwersyjnej (ES) wynosiła $660 \mathrm{~V}$.

Przedstawione wykresy zmiany lepkości plastycznej i granicy płynięcia w zależności od zmian temperatury potwierdzają tendencję wzrostu granicy płynięcia w płuczkach o stosunku fazy olejowej do wodnej wynoszącym 30/70.

W kolejnym etapie badań sprawdzono wpływ działania temperatury i ciśnienia na filtrację płuczek inwersyjnych. Filtrację płuczek badano na prasie filtracyjnej HPHT w temperaturach $50^{\circ} \mathrm{C}$ i $120^{\circ} \mathrm{C}$ przy ciśnieniu różnicowym $0,7 \mathrm{MPa}$. Badania wpływu podwyższonej temperatury i ciśnienia na wartość filtracji przeprowadzono dla płuczek inwersyjnych o stosunku fazy olejowej do wodnej wynoszącym 50/50, 40/60, 30/70 i 25/75. Wyniki badań przedstawiono w formie graficznej na rysunku 8.

Badania wykonane w temperaturze $20^{\circ} \mathrm{C}$ wykazały brak filtracji. W temperaturze $50^{\circ} \mathrm{C}$ filtracja płuczek inwersyjnych o stosunku o/w równym 50/50, 40/60 i 30/70 wynosiła $0,2 \mathrm{~cm}^{3} / 30 \mathrm{~min}$. Natomiast nieznacznie większą filtrację, równą $0,4 \mathrm{~cm}^{3} / 30 \mathrm{~min}$, stwierdzono dla płuczki o stosunku o/w wynoszącym 25/75 (rys. 8). Wraz ze wzrostem temperatury do $120^{\circ} \mathrm{C}$ wzrasta także filtracja płuczek. W płuczce o stosunku fazy olejowej do wodnej równym 50/50 i 40/60 filtracja wzrosła do $2 \mathrm{~cm}^{3} / 30 \mathrm{~min}$, a w płuczce o stosunku o/w równym $30 / 70$ - do $2,4 \mathrm{~cm}^{3} / 30 \mathrm{~min}$. Najwyższą wartość filtracji w temperaturze $120^{\circ} \mathrm{C}$ stwierdzono w płuczce inwersyjnej o stosunku fazy olejowej do wodnej wynoszącym 25/75 i była ona równa $3,6 \mathrm{~cm}^{3} / 30 \mathrm{~min}$ (rys. 8 ).

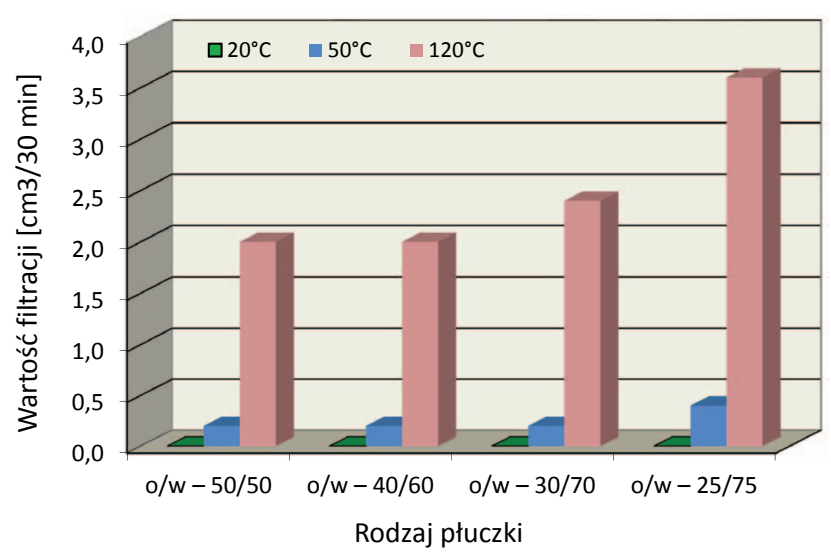

Rys. 8. Wielkość filtracji płuczek inwersyjnych w zależności od stosunku fazy olejowej do wodnej w temperaturach $20^{\circ} \mathrm{C}, 50^{\circ} \mathrm{C}$ i $120^{\circ} \mathrm{C}$ i przy ciśnieniu różnicowym $0,7 \mathrm{MPa}$

Fig. 8. Filtration loss of invert oil mud depending on the oil to water phase ratio at the temperature of 20,50 , and $120^{\circ} \mathrm{C}$ and a differential pressure of $0.7 \mathrm{MPa}$

\section{Wnioski}

1. Na podstawie badań laboratoryjnych nad doborem rodzaju i ilości emulgatorów dostosowanych do specyficznych 
warunków emulsji (większa objętość fazy wewnętrznej niż fazy ciągłej) wytypowano środki chemiczne, dzięki którym możliwe było uzyskanie stabilnych emulsji typu w/o o elektrycznej stabilności powyżej $300 \mathrm{~V}$ i akceptowalnych parametrach reologiczno-strukturalnych.

2. Analiza jakości, stabilności i odporności sporządzanych układów emulsyjnych pozwoliła na określenie optymalnych ilości emulgatorów dodawanych do danego typu emulsji. Do płuczek inwersyjnych o stosunku fazy olejowej do wodnej poniżej 50/50 należy stosować dodatek emulgatora ENI w ilości 4\% obj. oraz dodatek emulgatora ENII w ilości 2\% obj.

3. Właściwy dobór emulgatorów umożliwił opracowanie składów płuczek inwersyjnych bez udziału środków do zwiększania parametrów reologiczno-strukturalnych i dodatku materiałów obciążających. O gęstości opracowanych płuczek decyduje zawartość fazy wodnej, którą stanowi 35-procentowy roztwór $\mathrm{CaCl}_{2}$. Opracowane płuczki inwersyjne w zależności od zawartości fazy olejowej do wodnej mogą być stosowane bez udziału materiałów obciążających do określonej gęstości:

- płuczki inwersyjne o stosunku fazy o/w równym 40/60 - do gęstości $1140 \mathrm{~kg} / \mathrm{m}^{3}$;

- płuczki inwersyjne o stosunku fazy o/w równym 30/70 - do gęstości 1190 kg/m³

- płuczki inwersyjne o stosunku fazy o/w równym 20/80 - do gęstości $1230 \mathrm{~kg} / \mathrm{m}^{3}$.

4. Przeprowadzone badania płuczek w warunkach HTHP wykazały, że opracowane płuczki inwersyjne o stosunku fazy olejowej do wodnej mniejszym lub równym 50/50 charakteryzują się wysoką odpornością na działanie temperatury i ciśnienia. Płuczki inwersyjne zachowały stabilne parametry reologiczne $\mathrm{w}$ badanym zakresie temperaturowym do $120^{\circ} \mathrm{C}$ oraz charakteryzowały się niską filtracją - poniżej $3 \mathrm{~cm}^{3} / 30 \mathrm{~min}$.

5. W opracowanych płuczkach typu HIPR istnieje możliwość - w zależności od potrzeb - zmiany stosunku fazy olejowej do wodnej bez konsekwencji utraty jej stabilności. Przeprowadzone badania potwierdziły, że stosunek fazy olejowej do wodnej można zmieniać w zakresie od 30/70 do $70 / 30$.

6. Opracowane płuczki inwersyjne typu HIPR o wysokim stężeniu fazy wewnętrznej można przekształcić poprzez dodatek środka powierzchniowo czynnego w płuczkę emulsyjną typu o/w, którą można w łatwy sposób usunąć z otworu bez potrzeby stosowania specjalistycznych cieczy myjących. Cechą charakterystyczną opracowanych płuczek jest również to, że poprzez dodatek emulgatora ENII można z powrotem powrócić do płuczki inwersyjnej o właściwościach zbliżonych do płuczki wyjściowej.
7. Na podstawie wykonanych badań laboratoryjnych ustalono, że najefektywniejszym środkiem do zwilżania fazy stałej w płuczkach inwersyjnych o wysokiej zawartości fazy wewnętrznej będzie hydrofobizator Hw, który przy odpowiednim dawkowaniu na etapie wzbogacania płuczki w zwierconą fazę stałą o charakterze hydrofilowym powinien zapewnić utrzymanie elektrycznej stabilności płuczki inwersyjnej powyżej $300 \mathrm{~V}$.

8. Opracowane płuczki inwersyjne o stosunku fazy olejowej do wodnej poniżej lub równym 50/50 charakteryzują się bardzo dobrymi właściwościami inhibicyjnymi w stosunku do skał ilasto-łupkowych. Wartości odzysku łupku mioceńskiego dyspergowanego w temperaturze $20^{\circ} \mathrm{C}$ wynosiły od $98 \%$ do $100 \%$, natomiast w temperaturze $100^{\circ} \mathrm{C}$ - od $94 \%$ do $98 \%$. Na podstawie analizy uzyskanych wyników badań dyspersji należy stwierdzić, że opracowane płuczki inwersyjne mogą być stosowane do przewiercania skał ilasto-łupkowych.

Artykuł powstał na podstawie pracy statutowej pt. Odwracalne ciecze emulsyjne o wysokim stężeniu fazy wewnętrznej (HIPR) praca INiG - PIB na zlecenie MNiSW; nr zlec. 0044/KW/2020, nr archiwalny: DK-4100-0032/2020.

\section{Literatura}

Alford P., Anderson D., Bishop M., Goldwood D., Stouffer C., Watson E., Karonka M., Moore R., 2014. Novel oil based mud additive decreases HTHP fluid loss and enhances stability. AADE-14-FTCE-18.

Amani M., 2012. The rheological properties of oil-based mud under high pressure and high temperature conditions. Advances in Petroleum Exploration and Development, 3(2): 21-30. DOI:10.3968/j.aped.1925543820120302.359.

Amani M., Al-Jubouri M., Shadravan A., 2012. Comparative study of using oil-based mud versus water-based mud in HPHT fields. Advances in Petroleum Exploration and Development, 4(2): 18-27.

Błaż S., 2015. Badania laboratoryjne nad opracowaniem składu płuczki inwersyjnej. Nafta-Gaz, 3: 54-63.

Deville J.P., 2010. Inhibition of hydrolytic degradation in ester-based invert emulsion drilling fluids. $A A D E-10-D F-H O-47$.

Elkatatny S., 2019. Mitigation of barite sagging during the drilling of high-pressure high-temperature wells using an invert emulsion drilling fluid. Powder Technology, 352: 325-330. DOI: 10.1016/j. powtec.2019.04.037.

Fernandez J., Sharp K., Plummer D., 2014. Enhanced Fluid Viscosity Using Novel Surfactant Chemistry Purposely Designed for Low-Aromatic Mineral and Synthetic Base Fluids. AADE-14-FTCE-15.

Gacek M.M., Berg J.C., 2015. Effect of surfactant hydrophile-lipophile balance (HLB) value on mineral oxide charging in apolar media. Journal of Colloid and Interface Science, 449: 192-197. DOI:10.1016/j.jcis.2014.11.075.

Geng T., Qiu Z.S., Zhao Ch., Zhang L., Zhao X., 2019. Rheological study on the invert emulsion fluids with organoclay at high aged temperatures. Colloids and Surfaces A: Physicochemical and Engineering Aspects, 573: 211-221. DOI: 10.1016/j.colsurfa.2019.04.056. 
Hajiabadi S.H., Aghaei H., Ghabdian M., Kalateh-Aghamohammadi M. Esmaeilnezhad E., Choi H.J., 2020. On the attributes of invertemulsion drilling fluids modified with graphene oxide/inorganic complexes. Journal of Industrial and Engineering Chemistry, 93: 290-301. DOI: 10.1016/j.jiec.2020.10.005.

Holmberg K., Jönsson B., Kronberg B., Lindman B., 2002. Surfactants and Polymers in Aqueous Solution. John Wiley \& Sons, ISBN: 0-471-49883-1.

Jasiński B., 2012. Badania nad zastosowaniem emulsji olejowo-wodnych jako cieczy roboczych o obniżonej gęstości. Nafta-Gaz, 12: $1155-1164$.

Jones T.A., Mckellar A.J., Quintero L., 2006. Invert emulsion carrier fluid and oil-wetting agent and method of using same. Patent US 2006/0272815 A1.

Karimi A., Tahmasbi K., Arsanjani N., 2009. The feasibility study of replacing oil based mud with more environmentally acceptable paraffin based system in Iranian oil fields. Society of Petroleum Engineers. DOI: 10.2118/123519-MS.

Kulkarni S.D., Jamison D.E., 2015. Determining association of particles and emulsion in invert emulsion drilling fluids: experiments and modeling. AADE-15-NTCE-16.

Liu L., Pu X., Zhou Y., Zhou J., Luo D., Ren Z., 2020. Smart Pickering water-in-oil emulsion by manipulating interactions between nanoparticles and surfactant as potential oil-based drilling fluid. Colloids and Surfaces A: Physicochemical and Engineering Aspects, 586: 124246. DOI: 10.1016/j.colsurfa.2019.124246.

Luster M., Patel A.D., Lim S.K., 2015. Methods of using invert emulsion fluids with high internal phase concentration. Patent US 9,004,167 B2.

Maghrabi S., Wagle V., Teke K., Kulkarni D., Kulkarni K., 2011. Low plastic viscosity invert emulsion fluid system for HPHT wells. $A A D E-11-N T C E-15$.
Paswan B.K., Jain R., Sharma S.K., Mahto V., Sharma V.P., 2016. Development of Jatropha oil-in-water emulsion drilling mud system. Journal of Petroleum Science and Engineering, 144: 10-18. DOI: org/10.1016/j.petrol.2016.03.002.

Paswan B.K., Mahto V., 2020. Development of environment-friendly oil-in-water emulsion based drilling fluid for shale gas formation using sunflower oil. Journal of Petroleum Science and Engineering, 191: 107-129. DOI: 10.1016/j.petrol.2020.107129.

Rojas J.C., Daugherty B., Renfrow D., Bern P., Greene B., Irby R., Gusler B., Grover P., Trotter N., Dye B., 2007. Increased Deepwater Drilling Performance Using Constant Rheology Synthetic-based Mud. AADE-07-NTCE-20.

Tiwari R., Kumar S., Husein M.M., Rane P.M., Kumar N., 2020. Environmentally benign invert emulsion mud with optimized performance for shale drilling. Journal of Petroleum Science and Engineering, 186: 106791. DOI: 10.1016/j.petrol.2019.106791.

Whitby C.P., Fornasiero D., Ralston J., 2008. Effect of oil soluble surfactant in emulsions stabilised by clay particles. Journal of Colloid and Interface Science, 323: 410-419. DOI: 10.1016/j. jcis.2008.04.038

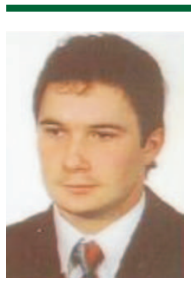

Mgr inż. Sławomir BŁAŻ

Starszy specjalista badawczo-techniczny w Zakładzie Technologii Wiercenia Instytut Nafty i Gazu - Państwowy Instytut Badawczy ul. Lubicz 25 A

31-503 Kraków

E-mail: slawomir.blaz@inig.pl

\section{OFERTA BADAWCZA ZAKŁADU PODZIEMNEGO MAGAZYNOWANIA GAZU}

- analiza struktur geologicznych ztóż gazu ziemnego, ropy naftowej oraz obiektów zawodnionych, pod kątem możliwości ich przekształcenia w PMG;

- szczegótowa analiza warunków geologiczno-złożowych, ocena dotychczasowej eksploatacji złoża, warunków hydrodynamicznych, zdolności wydobywczych odwiertów;

- ocena stanu technicznego istniejącej infrastruktury w aspekcie jej wykorzystania w pracy PMG;

· wykonywanie cyfrowych modeli geologicznych PMG, ztóż gazu ziemnego i ropy naftowej;

- wykonywanie projektów budowy PMG;

- analiza dotychczasowej pracy istniejących PMG w celu optymalizacji parametrów dalszej eksploatacji magazynów na bazie symulacji komputerowej;

- opracowanie projektów prac geologicznych, dotyczących poszukiwania i rozpoznawania ztóż gazu ziemnego i ropy naftowej;

opracowanie dokumentacji geologicznych ztóż ropy naftowej i gazu ziemnego;

- opracowanie programu optymalnej eksploatacji złoża, wydainości poszczególnych odwiertów, tempa sczerpywania itp.

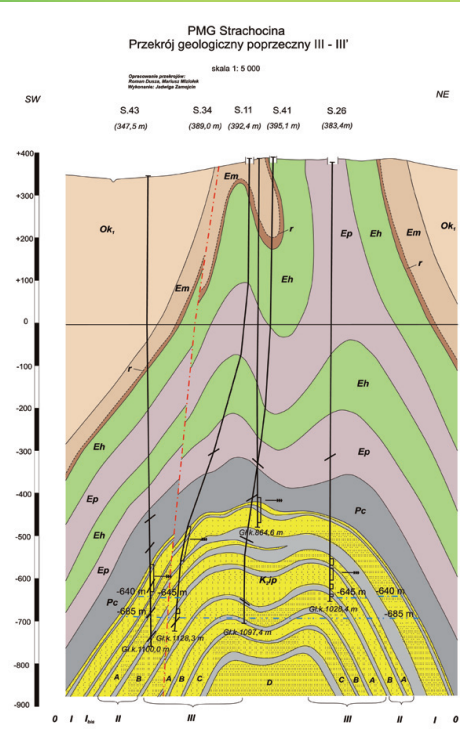

INSTYTUT NAFTY I GAZU

- Państwowy Instytut Badawczy 